\title{
IDENTIFIKASI KECEMASAN MATEMATIKA PADA MAHASISWA PROGRAM STUDI PENDIDIKAN GURU SEKOLAH DASAR
}

\author{
Sri Hartatik ${ }^{1)}$, Fifi Khoirul Fitriyah ${ }^{2)}$ \\ 1) Pendidikan Matematika, Universitas Nahdlatul Ulama Surabaya, Jawa Timur, Indonesia \\ Email: titax@unusa.ac.id \\ 2) Bimbingan dan Konseling, Universitas Nahdlatul Ulama Surabaya, Jawa Timur, Indonesia \\ E-mail:fifi@unusa.ac.id
}

\begin{abstract}
Abstrak. Tujuan penelitian adalah mengidentifikasi kecemasan matematika pada mahasiswa calon guru sekolah dasar. Pendekatan penelitian menggunakan pendekatan kuantitatif dengan metode expose facto. Analisis data menggunakan statistik deskriptif dengan mengacu pada standar deviasi dalam menentukan level kecemasan matematika. Hasil penelitian pada 146 mahasiswa Pendidikan Guru Sekolah Dasar (PGSD) Universitas Nahdlatul Ulama Surabaya (Unusa), diketahui sebanyak 32 mahasiswa (22\%) berada pada level kecemasan matematika tingkat tinggi, dan 21 mahasiswa (14\%) termasuk dalam kecemasan matematika tingkat rendah. Saran utama dari penelitian ini kepada peneliti selanjutnya adalah penting dirumuskan solusi atas permasalahan kecemasan matematika pada mahasiswa PGSD, mengingat mahasiswa PGSD adalah calon guru yang juga akan mengajarkan mata pelajaran matematika kepada murid-murid SD, sehingga harus terhindar dari masalah kecemasan matematika.
\end{abstract}

Kata Kunci: Kecemasan Matematika; Matematika; Guru; Mahasiswa

\section{Pendahuluan}

Matematika merupakan ilmu penting yang bermanfaat dalam kehidupan sehari-hari. Selain itu, matematika juga bermanfaat bagi pengembangan ilmu pengetahuan dan teknologi. Marpaung [1] menyatakan bahwa melalui matematika manusia dapat mendengarkan radio, menonton televisi, berkomunikasi melalui telepon maupun handphone. Sehingga sejarahpun membuktikan kehebatan ilmu matematika dan kebermanfaatan ilmu matematika dalam kehidupan manusia.

Bagi sebagain orang, matematika bahkan dianggap sebagai pemrediksi kecerdasan seseorang. Misalnya, jika ada seseorang yang berhasil mempelajari matematika dengan baik maka orang tersebut diprediksi akan mampu sukses pada bidang-bidang yang lainnya. Begitu pula sebaliknya, jika seseorang mengalami kesulitan dibidang matematika, maka diprediksi bahwa orang tersebut juga akan mengalami kesulitan dalam mempelajari hal-hal lainnya [2].

Di satu sisi matematika sangat penting dalam kehidupan sehari-hari, namun di sisi lain matematika dianggap sebagai salah satu mata pelajaran yang menjadi stressor utama dalam proses belajar di sekolah [3]. Berbagai pendapat menyebutkan penyebab seseorang mengalami kecemasan matematika. Wigfield dan Meece (dalam [3]) menjelaskan penyebab kecemasan terhadap pelajaran matematika adalah ketidak percayaan diri dalam menyelesaikan soal-soal matematika dan memiliki emosi negatif terhadap soal-soal matematika. Pendapat lain menyebutkan inteligensi sebagai alasan seseorang mengalami kecemasan matematika. Seseorang dengan inteligensi tinggi akan cenderung lebih tertarik pada matematika (Anggraeni, tanpa tahun). Pendapat berbeda juga disebutkan Hudoyo (Nawangsari, 2009), kecemasan seseorang terhadap matematika dipengaruhi oleh pengalaman belajar matematika yang diterima orang tersebut di masa lampau.

Permasalahan kecemasan terhadap matematika mengarah kepada ketidak sukaan siswa pada matematika sehingga berdampak pada menurunnya pemahaman terhadap matematika. Ketidakpahaman tersebut kemudian berdampak pada ketidakmampuan dalam menyelesaikan tugas seharihari lainnya [4]. Hasil penelitian meta analisis oleh Hembree [5] terhadap 151 mahasiswa juga menyebutkan bahwa kecemasan matematika berhubungan dengan lemahnya kemampuan seseorang dalam mengerjakan soal-soal matematika.

Sarason (dalam Nawangsari, 2000) melaporkan hasil studi longitudinal yang intensif pada 700 siswa Sekolah 
Dasar di mana siswa akan memperoleh nilai matematika yang rendah ketika diberikan tes matematika tanpa ada pemberitahuan sebelumnya yang membuat siswa menjadi tidak siap, hal ini dikarenakan oleh situasi dan suasana tes yang membuat mereka cemas.

Banyak siswa yang mengalami kecemasan matematika memiliki sedikit kepercayaan diri pada kemampuan dirinya dalam mengerjakan matematika dan cenderung sedikit untuk mengambil mata pelajaran yang berkaitan dengan hitung menghitung, sehingga berdampak pada pembatasan pilihan karir [6]. Selain itu, kecemasan matematika juga berpengaruh negatif pada kesuksesan siswa ([5], [7]) dan proses belajar ([8], [9]).

Bukan hanya siswa yang mengalami kecemasan matematika, mahasiswa yang notabene calon guru juga mengalaminya. Dalam penelitiannya, Stoehr [10] menyebutkan bahwa guru Sekolah Dasar sebaiknya memiliki kompetensi dan kepercayaan diri yang tinggi dalam mengajarkan matematika. Banyak calon-calon guru SD perempuan memilih untuk berkarir dengan mengajar matematika, sehingga mereka harus terhindar dari kecemasan matematika. Berdasarkan perspektif calon-calon guru SD perempuan, kecemasan matematika adalah ketakutan.

Salah satu universitas yang memiliki program studi Pendidikan Guru Sekolah Dasar (PGSD) adalah Universitas Nahdlatul Ulama (Unusa). Dalam penelitian, peneliti ingin mengidentifikasi masalah kecemasan matematika pada mahasiswa prodi PGSD Unusa.

\section{MetODE}

Penelitian ini menggunakan pendekatan kuantitatif dengan metode expose facto. Subjek penelitian adalah seluruh mahasiswa PGSD Unusa yang pernah atau sedang memprogram mata kuliah matematika 1 atau matematika 2. Analisis data penelitian menggunakan statistik deskriptif sehingga dapat diketahui kategori level kecemasan matematika mahasiswa.

Instrumen penelitian mengadaptasi Math Anxiety Rating Scale (MARS) kedalam Bahasa Indonesia. Uji coba MARS pada mahasiswa di beberapa negara terbukti valid dan reliabel ([11], [12]), termasuk uji coba MARS versi Bahasa Indonesia juga terbukti valid dan reliabel $(\alpha=0.79)$.

\section{HASIL DAN PEMBAHASAN}

\section{A. Hasil}

Tujuan penelitian ini adalah untuk menemukan gambaran masalah kecemasan matematika pada mahasiswa program studi PGSD Unusa. Berdasarkan hasil penelitian ditemukan gambaran sebagaimana dijelaskan pada tabel I.
TABEL I

GAMBARAN LEVEL KECEMASAN MATEMATIKA MAHASISWA

\begin{tabular}{cccc}
\hline No. & $\begin{array}{c}\text { Level Kecemasan } \\
\text { Matematika }\end{array}$ & $\begin{array}{c}\text { Jumlah } \\
\text { Mahasiswa }\end{array}$ & Persentase \\
\hline 1 & Tinggi & 32 & $22 \%$ \\
2 & Sedang & 93 & $64 \%$ \\
3 & Rendah & 21 & $14 \%$ \\
\hline \multicolumn{2}{c}{ Total } & 146 & $100 \%$
\end{tabular}

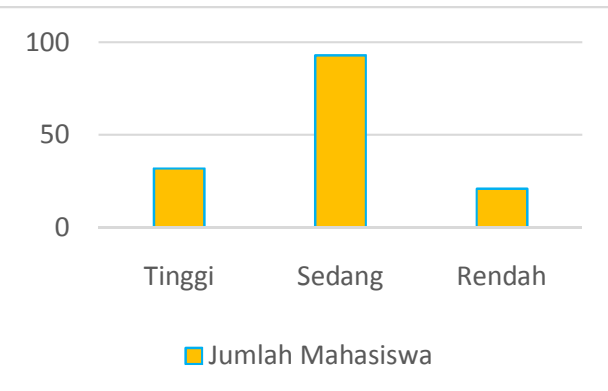

Grafik 1. Gambaran Level Kecemasan Matematika Mahasiswa

Berdasarkan tabel I dan grafik 1 menunjukkan bahwa level kecemasan matematika dibagi menjadi tiga kategori yakni tinggi, rendah, dan sedang. Hasil penelitian menemukan sebanyak 32 mahasiswa $(22 \%)$ program studi PGSD Unusa berada pada level kecemasan matematika tingkat tinggi, sedangkan 21 mahasiswa (14\%) berada pada level kecemasan matematika tingkat rendah.

\section{B. Pembahasan}

Guru SD merupakan ujung tombak dalam menyukseskan pembelajaran di tingkat SD. Merujuk pada tugas guru SD sebagai guru kelas, maka mereka diharuskan menguasai semua bidang studi termasuk khususnya matematika. Hasil penelitian menunjukkan angka yang fantastis dalam kasus kecemasan matematika pada guru SD yakni mencapai $22 \%$. Data tersebut menjadi asesmen awal dalam memperbaiki kualitas pembelajaran matematika di SD melalui aspek guru.

Kecemasan merupakan ketakutan yang telah lama terbukti menyelimuti guru-guru SD dalam mengajar matematika [10]. Di sisi lain, matematika sangat dibutuhkan. Stoehr [10] juga menyatakan bahwa mengajar matematika merupakan pilihan karir yang tepat bagi para guru. Sehingga guru-guru perlu terhindar dari masalah kecemasan matematika.

Sebelum bertindak mengatasi kecemasan matematika pada siswa yang juga trend sejak lama [6], maka mengatasi kecemasan gurunya adalah lebih penting. Oleh karena itu, perlu adanya intervensi melalui kegiatan bimbingan dan konseling di perguruan tinggi dalam memfasilitasi mahasiswa calon guru SD mereduksi kecemsan matematia. 


\section{IV.KESIMPULAN DAN SARAN}

Kesimpulan penelitian adalah ditemukannya angka yang cukup fantastis dalam kasus kecemasan matematika pada calon guru SD yang notabene adalah mahasiswa program studi PGSD Unusa. Sebanyak 22\% mahasiswa berada pada kategori kecemasan matematika tingkat tinggi dan 14\% pada level kecemasan matematika tingkat rendah.

Rekomendasi dari penelitian ini kepada penelitian selanjutnya adalah:

1) Penelitian ini merupakan pijakan dalamupaya merancang intervensi penanganan kecemasan matematika melalui serangkaian kegiatan terapeutik yang termasuk dalam pelayanan bimbingan dan konseling di Perguruan Tinggi.

2) Fenomena kecemasan matematika juga penting untuk diteliti bukan hanya pada level mahasiswa, melainkan juga pada siswa SD, SMP, dan SMA.

3) Perlu adanya penelitian tentang faktor-faktor yang memengaruhi kecemasan matematika.

\section{DAFTAR PUSTAKA}

[1] Marpaung, Y. (2004). Reformasi Pendidikan Matematika di Sekolah Dasar. Basis, No 7-8, 14-20.

[2] Shadiq F. (2007). Apa Dan Mengapa Matematika Begitu Penting?. Departemen Pendidikan Nasional Direktorat Jenderal Peningkatan Mutu Pendidik Dan Tenaga Kependidikan Pusat Pengembangan Dan Pemberdayaan Pendidik Dan Tenaga Kependidikan (PPPPTK) Matematika.

[3] Ormrod, J.E. (2004). Human Learning (4th Edition). Ohio : Pearson.

4] Jbeili, I.M.A. (2003). The Effect of Metacognitive Scaffolding \& Cooperativelearning on Mathematics performance and Mathematical reasoningamong Fifth-grade students in Jordan. Unpublished doctoraldissertation. Penang : University of Science Malaysia.

[5] Hembree, Ray. (1990). The Nature, Effects, and Relief of Mathematics Anxiety. Journal for Research in Mathematics Education, Vol. 21 No.1 (Jan 1990), pp. 33-46.

[6] Scarpello, G. (2007). Helping students get past math anxiety. Techniques:Connecting Education and Careers. 82(6), 34-35.

[7] Thomas, P., Higbee, J., (1999). Affective and cognitive factors related to mathematics achievement. Journal of Developmental Education, 23, 1, 8-16.
[8] Sloan, T., Daane, C., Geisen, J., (2002). Mathematics anxiety and learningstyles: What is the relationship in elementary pre-service teachers? School Science and Mathematics, 84-87.

[9] Vinson, B., (2001). A comparison of pre-service teachers mathematics anxiety before and after a methods class emphasizing manipulatives. Early Childhood Education Journal, 29, 2, 89-94.

[10] Stoehr, Kathleen Jablon. (2017). Mathematics Anxiety One Size Does Not Fit All. Journal of Teacher Education, Vol 68, Issue 1, 2017.

[11] Richardson, F. C., \& Suinn, R. M. (1972). The Mathematics Anxiety Rating Scale: Psychometric data. Journal of Counseling Psychology, 19(6), 551-554. http://dx.doi.org/10.1037/h0033456.

[12] Suinn RM., \& Winston EH. 2003. The Mathematics Anxiety Rating Scale, a Brief Version: Psychometric Data. Psycho Rep, 2003 Feb 92 (1): 167-73 DOI: $\underline{10.2466 / p r 0.2003 .92 .1 .167}$ 